\title{
MAP3K3 Gene
}

National Cancer Institute

\section{Source}

National Cancer Institute. MAP3K3 Gene. NCI Thesaurus. Code C125112.

This gene plays a role in mitogen-activated kinase signaling pathways. 